\title{
Haloalkane degradation and assimilation by Rhodococcus rhodochrous NCIMB 13064
}

\author{
Helen Curragh, ${ }^{1,2,4}$ Orla Flynn, ${ }^{1}$ Michael J. Larkin, ${ }^{1,2}$ Thomas M. \\ Stafford, ${ }^{1,2,4}$ John T. G. Hamilton ${ }^{3}$ and David B. Harper ${ }^{1,3,4}$ \\ Author for correspondence: Michael J. Larkin. Tel: +44232245133 ext. 2288/4390 (QUESTOR \\ +44232 335577). Fax: +44232 236505 (QUESTOR + 44232 661462).
}

1 The Questor Centre, David Keir Building, The Queen's University of Belfast, Belfast BT9 5AG, UK

2 School of Biology and Biochemistry, Medical Biology Centre, The Queen's University of Belfast, Belfast BT9 7BL, UK

${ }^{3}$ Food and Agricultural Chemistry Research Division, Department of Agriculture for Northern Ireland, Newforge Lane, Belfast BT9 5PX, UK

4 Microbial Biochemistry Section, Department of Food Science, The Queen's University of Belfast, Newforge Lane, Belfast BT9 5PX, UK
The bacterium Rhodococcus rhodochrous NCIMB 13064, isolated from an industrial site, could use a wide range of 1-haloalkanes as sole carbon source but apparently utilized several different mechanisms simultaneously for assimilation of substrate. Catabolism of 1-chlorobutane occurred mainly by attack at the C-1 atom by a hydrolytic dehalogenase with the formation of butanol which was metabolized via butyric acid. The detection of small amounts of $\gamma$-butyrolactone in the medium suggested that some oxygenase attack at C-4 also occurred, leading to the formation of 4-chlorobutyric acid which subsequently lactonized chemically to $\gamma$-butyrolactone. Although 1 chlorobutane-grown cells exhibited little dehalogenase activity on 1chloroalkanes with chain lengths above $C_{10}$, the organism utilized such compounds as growth substrates with the release of chloride. Concomitantly, $\gamma$-butyrolactone accumulated to $1 \mathrm{mM}$ in the culture medium with 1 chlorohexadecane as substrate. Traces of 4-hydroxybutyric acid were also detected. It is suggested that attack on the long-chain chloroalkane is initiated by an oxygenase at the non-halogenated end of the molecule leading to the formation of an $\omega$-chlorofatty acid. This is degraded by $\beta$-oxidation to 4chlorobutyric acid which is chemically lactonized to $\gamma$-butyrolactone which is only slowly further catabolized via 4-hydroxybutyric acid and succinic acid. However, release of chloride into the medium during growth on long-chain chloroalkanes was insufficient to account for all the halogen present in the substrate. Analysis of the fatty acid composition of 1-chlorohexadecane-grown cells indicated that chlorofatty acids comprised $75 \%$ of the total fatty acid content with $C_{14: 0}, C_{16: 0}, C_{16: 1}$ and $C_{18: 1}$ acids predominating. Thus the incorporation of 16-chlorohexadecanoic acid, the product of oxygenase attack directly into cellular lipid represents a third route of chloroalkane assimilation. This pathway accounts at least in part for the incomplete mineralization of long-chain chloroalkane substrates. This is the first report of the coexistence of a dehalogenase and the ability to incorporate long-chain haloalkanes into the lipid fraction within a single organism and raises important questions regarding the biological treatment of haloalkane containing effluents.

Keywords: Rhodococcus rbodocbrous, haloalkanes, degradation, chlorofatty acids, lipid composition

\section{INTRODUCTION}

Many haloalkanes are resistant to microbial attack and persist in the environment to become major pollutants of the biosphere and ground water. The rate of biodegradation of these compounds is largely determined by the rate of cleavage of the carbon-halogen bond. Three principal mechanisms of microbial dehalogenation have been identified, namely oxidative, reductive and hydrolytic. Oxidative dehalogenation is usually mediated by relatively non-specific monooxygenases which catalyse the formation of gem-halohydrins or halogenated epoxides which spontaneously decompose to aldehydes releasing halide ion. In general, such enzymes attack short-chain halo- 
carbons $\left(\mathrm{C}_{1}\right.$ to $\left.\mathrm{C}_{4}\right)$. Thus ammonia monooxygenase of the nitrifying bacterium Nitrosomonas europaea dehalogenated all monohaloethanes and $\mathrm{C}_{1}$ to $\mathrm{C}_{4}$ monochlorinated $\mathrm{n}$ alkanes (Rasche et al., 1990; Vannelli et al., 1990). Similarly the broad substrate specificity of methane oxygenase in methanotrophic organisms allows it to dehalogenate a variety of $\mathrm{C}_{1}$ and $\mathrm{C}_{2}$ compounds. Resting cells of Methanococcus capsulatus can convert chloromethane to formaldehyde (Stirling \& Dalton, 1979) whilst the soluble methane oxygenase of Methylomonas sp. and Metbylosinus sp. is able to dehalogenate, in addition to $C_{1}$ compounds, $\mathrm{C}_{2}$ compounds such as trans-1,2-dichloroethylene via chloroxirane type intermediates (Oldenhuis et al., 1989; Janssen et al., 1988b).

Reductive dehalogenation of a range of chlorinated alkanes and alkenes by methanogenic, denitrifying and sulphate reducing organisms has been observed in reducing environments in nature (Vogel \& McCarty, 1985; Bouwer \& McCarty, 1983; Bagley \& Gossett, 1990). The precise enzymic mechanism has not been defined but there is evidence that reduced porphyrin and corrin complexes are able to dehalogenate halogenated compounds efficiently (Marks et al., 1989).

Hydrolytic dehalogenation of haloalkanes involving release of halide ion and formation of the corresponding alcohol has been reported in a number of organisms. D. B. Janssen and co-workers (Janssen et al., 1985; Keuning et al., 1985) have isolated two halidohydrolases with different substrate specificities from a nitrogen fixing hydrogen bacterium Xantbobacter sp. able to use 1,2dichloroethane and $C_{1}$ to $C_{4}$ terminally halogenated alkanes as sole carbon and energy source. Similar enzymes are produced by several strains of Ancylobacter aquaticus, a facultative methylotroph also able to use dichloroethane as sole carbon and energy source (Van den Wijngaard et al., 1992). This group has also purified a broad spectrum halidohydrolase from an Acinetobacter sp. capable of degrading $C_{2}$ to $C_{9}$ terminally halogenated alkanes (Janssen et al., 1987, 1988a).

T. Leisinger and co-workers (Scholtz et al., 1987a, b, 1988) have shown that at least three different haloalkane dehalogenases can be induced in an Artbrobacter sp. with a broad range of growth substrates. They described the purification of one of these dehalogenases capable of attacking a wide variety of halogenated compounds. Similar enzymes have been isolated by Yokata et al. (1987) from a Corynebacterium sp. and by Sallis et al. (1990) from Rhodococcus erythropolis. An interesting variant of the hydrolytic dehalogenation mechanism in which glutathione acts as a co-factor has been described in a dichloromethane-utilizing methanotrophic Hyphomicrobium sp. In this organism an inducible glutathione- $S$ transferase catalyses the nucleophilic displacement of chloride by reduced glutathione which decomposes chemically to formaldehyde and glutathione (Stucki et al., 1981; Kohler-Staub \& Leisinger, 1985).

The assimilation of longer-chain chloroalkanes by organisms does not necessarily involve dehalogenation. Thus Murphy \& Perry $(1983,1984)$ have shown that Myco- bacterium spp. and certain fungi, when growing on 1chlorohexadecane or 1-chlorooctadecane as sole carbon and energy source, can incorporate these compounds as the corresponding chlorinated fatty acids into the cellular lipid fraction of the organism in high yield. Transformation into chlorinated fatty acids of both longer and shorter chain-length also occurred so that chlorinated fatty acids could account for $85 \%$ of the total fatty acid content. It was not clear from these reports whether these organisms possessed a dehalogenase allowing complete metabolism of the haloalkane or whether $\beta$-oxidation of the substrate proceeded until proximity of the halogen prevented further degradation.

In this paper we describe an investigation of the growth on a variety of haloalkanes of Rbodococcus rbodocbrous NCIMB 13064, an organism which appears to use several different mechanisms simultaneously for haloalkane assimilation.

\section{METHODS}

Isolation and culture of organism. Rhodococcus rhodochrous NCIMB 13064 was isolated by elective culture from a soil sample obtained from an industrial site which had previously been exposed to chlorinated alkanes. The minimal salts medium used contained $1.5 \mathrm{mM} 1$-chlorobutane.

The organism was grown routinely in $500 \mathrm{ml}$ conical flasks sealed with Teflon lined screw caps fitted with Mini-inert sampling ports (Precision Sampling Co.) containing $200 \mathrm{ml}$ of medium of the following composition $\left(\mathrm{g} \mathrm{l}^{-1}\right): \mathrm{NaH}_{2} \mathrm{PO}_{4} \cdot 2 \mathrm{H}_{2} \mathrm{O}$ $(1 \cdot 6) ; \mathrm{Na}_{2} \mathrm{HPO}_{4}(1 \cdot 4) ;\left(\mathrm{NH}_{4}\right)_{2} \mathrm{SO}_{4}(0 \cdot 5) ; \mathrm{MgSO}_{4} .7 \mathrm{H}_{2} \mathrm{O}(0 \cdot 2)$; $\mathrm{K}_{2} \mathrm{SO}_{4}(0 \cdot 5)$. The $\mathrm{pH}$ of the solution was adjusted to $7 \cdot 0$ and the medium supplemented with a trace element solution $\left(10 \mathrm{ml} \mathrm{l}^{-1}\right)$ containing $\left(\mathrm{g} \mathrm{I}^{-1}\right)$ : $\mathrm{Na}_{2}$ EDTA. $2 \mathrm{H}_{2} \mathrm{O}(12 \cdot 0) ; \mathrm{FeSO}_{4} \cdot 7 \mathrm{H}_{2} \mathrm{O}$ $(2 \cdot 0) ; \mathrm{CaCl}_{2}(1 \cdot 0) ; \mathrm{ZnSO}_{4} \cdot 7 \mathrm{H}_{2} \mathrm{O}(0 \cdot 4) ; \mathrm{MnSO}_{4} \cdot 4 \mathrm{H}_{2} \mathrm{O}(0 \cdot 4)$; $\mathrm{CuSO}_{4} \cdot 5 \mathrm{H}_{2} \mathrm{O}(0 \cdot 1)$. 1-Chlorobutane $(1 \cdot 1 \mathrm{mmol}, 115 \mu \mathrm{l})$ was injected through the sampling port of the flask giving an aqueous phase concentration of $2.8 \mathrm{mM}$ after equilibration of aqueous and gaseous phases in the flask. Cultures were incubated at $25^{\circ} \mathrm{C}$ on an orbital shaker $(200$ r.p.m.). When cultured on less volatile long-chain alkanes such as hexadecane and 1chlorohexadecane flasks were stoppered with cotton wool and contained $200 \mathrm{ml}$ of culture medium plus $1 \mathrm{mmol}$ of substrate.

Growth of the organism was monitored by measuring the optical density at $690 \mathrm{~nm}$. During growth on long-chain alkanes, cells tended to clump together and it was necessary to homogenize the culture prior to measurement of optical density.

Chemicals. 1-Chlorobutane (HPLC grade, purity $>99.5 \%$ ) and 1-chlorohexadecane (purity $>95 \%$ ) were obtained from Aldrich. Analysis by gas chromatography/mass spectrometry (GC/MS) showed that concentrations of 4-chlorobutanol and 1,4-dichlorobutane did not exceed 5 p.p.m. in 1-chlorobutane. Similarly, no individual homologue present as an impurity in 1chlorohexadecane exceeded a concentration of $0.5 \%$. All other chemicals used as substrates were purchased from Aldrich except 1-bromopentadecane which was obtained from Fluka.

Halide analysis. Chloride and bromide ions in centrifuged culture medium were determined by potentiometric titration using a Corning Chloride Analyser 926. Fluoride ion was measured using an Orion model 94-09 combination fluoride electrode.

1-Chlorobutane determination. 1-Chlorobutane in culture medium was determined by gas chromatography using a head- 
space assay. Samples of head-space $(1 \mathrm{ml})$ were withdrawn from culture flasks through the sampling port and injected into a Pye Unicam 104 (model 74) gas chromatograph fitted with a flame ionization detector and equipped with a glass column $(1.5 \mathrm{~m} \times$ $2 \mathrm{~mm}$ ) packed with Tenax GC (60-80 mesh) and operated at a nitrogen gas flow of $20 \mathrm{ml} \mathrm{min}^{-1}$. The oven temperature was programmed at a rate of 24 Centigrade degrees $\mathrm{min}^{-1}$ from 60 to $200^{\circ} \mathrm{C}$.

Calibration was against samples of head-space from above 1chlorobutane solutions $(2 \mathrm{ml})$ of known concentration equilibrated at $25^{\circ} \mathrm{C}$ in $25 \mathrm{ml}$ screw capped septum vials sealed with Tefon lined silicone discs. The partition coefficient water/air (w/v per w/v) for 1 -chlorobutane at $25^{\circ} \mathrm{C}$ was found to be 1.51 at $25{ }^{\circ} \mathrm{C}$.

1-Chlorohexadecane determination. Cells, which tended to grow in clumps, were removed using either filtration (Whatman no. 50 paper) or a separating funnel $(500 \mathrm{ml})$. The resulting culture medium $(200 \mathrm{ml})$ was extracted with light petroleum (b.p. $40-60^{\circ} \mathrm{C}, 3 \times 25 \mathrm{ml}$ ) and the extracts bulked. The cells harvested from the medium were washed with light petroleum (b.p. $\quad 40-60^{\circ} \mathrm{C}, 3 \times 10 \mathrm{ml}$ ) to remove residual 1 chlorohexadecane. The resulting extracts were combined with those from the culture medium and evaporated to small volume.

1-Chlorohexadecane was determined in the extract by gas chromatography using a Hewlett Packard 5890 fitted with a flame ionization detector and equipped with an Ultra 1 fused silica WCOT column $(25 \mathrm{~m} \times 0.32 \mathrm{~mm})$ with $100 \%$ dimethylpolysiloxane as bonded phase. Helium was used as the carrier gas at a flow rate of $1.5 \mathrm{ml} \mathrm{min}^{-1}$. After sample injection using a split ratio of $200: 1$ the oven temperature was held at $100^{\circ} \mathrm{C}$ for $1 \mathrm{~min}$ and then programmed at 10 Centigrade degrees $\mathrm{min}^{-1}$ to $250^{\circ} \mathrm{C}$. 1-Chlorohexadecane was quantified by comparison of the peak area at the retention time of the compound with that of a standard solution of the compound.

Identification and quantitation of metabolic intermediates. Culture medium $(400 \mathrm{ml})$ after centrifugation to remove cells was divided into two equal portions. For extraction of organic acids (i.e. n-butyric, 4-chlorobutyric, 4-hydroxybutyric and succinic acids) a portion was adjusted to $\mathrm{pH} 2.0$ and continuously extracted with diethyl ether for $72 \mathrm{~h}$. The ether extract was dried with anhydrous $\mathrm{MgSO}_{4}$ and evaporated to small volume. Acids were converted to methyl esters by addition of an equal volume of a solution of diazomethane in ether and this derivatized extract was utilized for GC/MS. For isolation of $\gamma$ butyrolactone, culture medium was continuously extracted with diethyl ether for $72 \mathrm{~h}$ without prior $\mathrm{pH}$ adjustment. The ether extract was dried with anhydrous $\mathrm{MgSO}_{4}$ and evaporated to small volume prior to analysis by GC/MS.

Both $\gamma$-butyrolactone and methyl esters of organic acids were identified and quantified on a Hewlett Packard 5890 gas chromatograph linked to a HP5970 mass selective detector. The GC was fitted with a CP-SIL-19 fused silica WCOT column $(25 \mathrm{~m} \times 0.25 \mathrm{~mm})$ with a bonded phase of $7 \%$ cyano, $7 \%$ phenyl, $85 \%$ methyl, $1 \%$ vinylpolysiloxane. Helium was used as the carrier gas at a flow rate of $0.75 \mathrm{ml} \mathrm{min}{ }^{-1}$. After splitless injection of sample the oven temperature was held at $30^{\circ} \mathrm{C}$ for $2 \mathrm{~min}$ and programmed at 10 Centigrade degrees $\mathrm{min}^{-1}$ to $275^{\circ} \mathrm{C}$. Ion currents between $\mathrm{m} / \mathrm{e} 30$ and $\mathrm{m} / \mathrm{e} 350$ were monitored. Compounds were identified from their mass spectra and retention time. To quantify each compound the total ion current at the retention time of the compound was compared with that of an authentic sample of the compound of known concentration.

$\mathrm{n}$-Butanol was determined by gas chromatography of the culture medium by the method of Elfaki et al. (1991).
Measurement of oxygen uptake by cell suspensions. Cultures $(200 \mathrm{ml})$ were grown as described above. Oxygen consumption by whole cell suspensions was recorded at $25^{\circ} \mathrm{C}$ with a $4 \mathrm{ml}$ capacity Clark-type oxygen electrode (Rank Bros.). Incubation mixtures contained $50 \mathrm{mM}$ phosphate buffer $\mathrm{pH} 7 \cdot 0$, cell suspension $(12.6 \mathrm{mg}$ wet $\mathrm{wt}$ ) and $1 \mathrm{mM}$ substrate in a total volume of $3 \mathrm{ml}$. Butane was added as a stock solution $(10 \mathrm{mM})$ prepared by weighing an aqueous butane gas solution stored in screw capped septum vials sealed with Teflon lined silicone discs.

Measurement of dehalogenating activity in resting cells. Cultures $(200 \mathrm{ml})$ were grown aerobically on 1 -chlorobutane, as described previously. Cells were harvested in the exponential phase by centrifugation, washed with Tris $/ \mathrm{H}_{2} \mathrm{SO}_{4}$ buffer $(50 \mathrm{mM}, \mathrm{pH} 8.0)$ and resuspended in the buffer $(50 \mathrm{ml})$ in $250 \mathrm{ml}$ medical flat bottles sealed with Teflon lined screw caps. Dehalogenation of a given substrate by these resting cell suspensions was measured by addition of $0.375 \mathrm{mmol}$ substrate $(7.5 \mathrm{mM}$ final concentration) and incubation of the suspension at $25^{\circ} \mathrm{C}$ with shaking for $24 \mathrm{~h}$. Cells were then removed by centrifugation and the supernatant was analysed for halide ion. Controls containing buffer and substrate alone were used to measure any abiotic dehalogenation and additional controls containing cell suspensions in the absence of substrate were employed to assess release of endogenous halide ion by cells. Net biological dehalogenation of each substrate was calculated by subtracting the sum of abiotic halide release from the substrate and halide release from cells in the absence of substrate from halide release by the cells in the presence of substrate. All experiments were performed in duplicate. Cellular dehalogenation activity for each substrate is recorded as the release of halide ion (in mmols) expressed as a percentage of the total chloride ion released (in mmols) from 1-chlorobutane under the same conditions.

Determination of fatty acid composition of lipids of $R$. rhodochrous. Cells $(5 \mathrm{~g}$ wet $\mathrm{wt})$ were harvested by centrifugation, washed with light petroleum (b.p. $40-60^{\circ} \mathrm{C}, 3 \times 20 \mathrm{ml}$ ) to remove residual substrate. Cellular fatty acids were converted directly to the corresponding methyl esters by the transesterification method of Dunlap \& Perry (1967). Wet cells (1 g wet wt) were suspended in $14 \% \mathrm{BF}_{3}$ in methanol/benzene $(9: 1$, $\mathrm{v} / \mathrm{v} ; 4 \mathrm{ml}$ ) and heated for $12 \mathrm{~h}$ at $60^{\circ} \mathrm{C}$ in a water bath in a glass stoppered tube. After cooling, water $(8 \mathrm{ml})$ was added and the mixture extracted with light petroleum (b.p. $40-60^{\circ} \mathrm{C}$, $2 \times 10 \mathrm{ml}$ ). The extracts were combined, washed with water $(10 \mathrm{ml})$ and concentrated to $1 \mathrm{ml}$.

To extract free fatty acids from cells of R. rbodocbrous, cells $(5 \mathrm{~g}$ wet wt) after washing with light petroleum as described above were adjusted to $\mathrm{pH} 2.0$ and extracted with diethyl ether $(3 \times 30 \mathrm{ml})$. The combined ether extract was shaken with saturated $\mathrm{NaHCO}_{3}(2 \times 20 \mathrm{ml})$. The aqueous extract was washed with diethyl ether $(20 \mathrm{ml})$, acidified to $\mathrm{pH} 2.0$ and re-extracted with diethyl ether $(3 \times 30 \mathrm{ml})$. The extract was reduced to a small volume and the acids were methylated as described above. Fatty acid methyl esters (FAME) were identified and quantified by GC/MS on a Hewlett Packard 5890 gas chromatograph linked to an HP 5970 mass selective detector controlled by an HP 300 series computer. The gas chromatograph was fitted with a CP-SIL-88 fused silica WCOT column $(50 \mathrm{~m} \times 0.25 \mathrm{~mm})$ with $100 \%$ cyanopropylpolysiloxane as bonded phase. Helium was used as the carrier gas at a flow rate of $0.75 \mathrm{ml} \mathrm{min}^{-1}$. After splitless injection of the sample the oven temperature was held at $130^{\circ} \mathrm{C}$ for $5 \mathrm{~min}$, then programmed at 5 Centigrade degrees $\mathrm{min}^{-1}$ up to $230^{\circ} \mathrm{C}$ and held at the temperature for $15 \mathrm{~min}$. Ion currents between $\mathrm{m} / \mathrm{e} 30$ and 500 were monitored. Individual FAME were identified from their mass spectra and retention times (Murphy \& Perry, 1983). To quantify each 


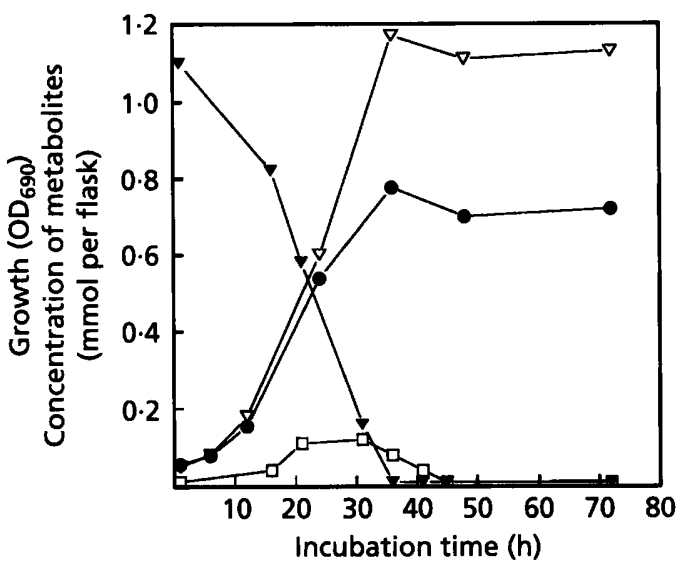

Fig. 1

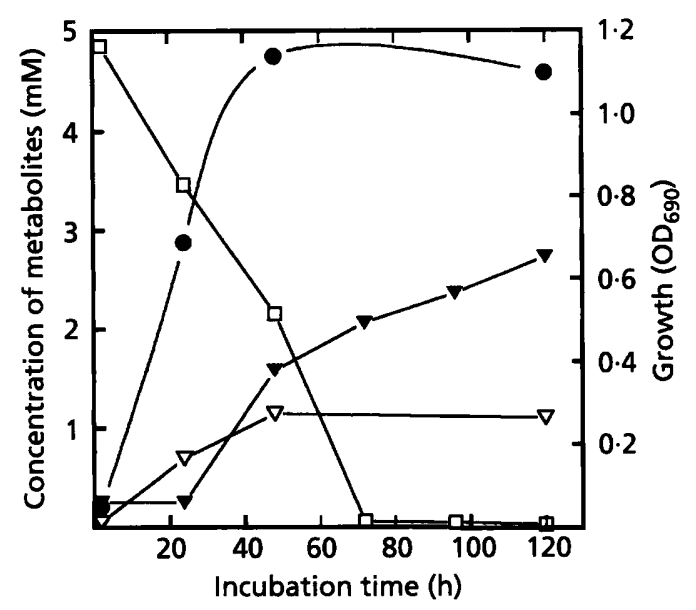

Fig. 2

Fig. 1. Growth of $R$. rhodochrous NCIMB 13064 on 1-chlorobutane. The organism was grown at $25^{\circ} \mathrm{C}$ in $500 \mathrm{ml}$ sealed flasks containing $200 \mathrm{ml}$ of minimal salts medium to which $1.1 \mathrm{mmol} 1$-chlorobutane was added. Growth and metabolite concentrations were measured as described in Methods. - , Growth; $\nabla$, chloride concn; $\nabla, 1$-chlorobutane concn; $\square$, butyric acid concn.

Fig. 2. Growth of $R$. rhodochrous NCIMB 13064 on 1-chlorohexadecane. The organism was grown at $25^{\circ} \mathrm{C}$ in $500 \mathrm{ml}$ flasks stoppered with cotton wool on $200 \mathrm{ml}$ of minimal salts medium containing $5 \mathrm{mM}$ 1-chlorohexadecane. Growth and metabolite concentrations were measured as described in Methods. Growth; $\nabla$, chloride concn; $\square$, 1chlorohexadecane concn; $\nabla, \gamma$-butyrolactone concn.

FAME the total ion current at the retention time of the compound was expressed as a percentage of the sum of the ion currents associated with all the FAME in the extract.

\section{RESULTS}

\section{1-Chlorobutane degradation by $R$. rhodochrous}

The time course of growth of $R$. rbodochrous on 1chlorobutane measured as optical density at $690 \mathrm{~nm}$ is shown in Fig. 1. The accumulation of chloride ion in the medium closely parallels growth and is consistent with the disappearance of 1-chlorobutane from the medium. nButyric acid also accumulates transiently in the medium during growth attaining a peak concentration of $0.12 \mathrm{mmol}$ per flask during the exponential phase of growth. Additionally, culture medium sampled at 21 and $31 \mathrm{~h}$ contained n-butanol at concentrations of $0.024 \mathrm{mmol}$ per flask and $0.016 \mathrm{mmol}$ per flask respectively. The presence of these intermediates suggested that degradation of substrate was initiated by attack on the carbon atom attached to the halogen atom. Further evidence of catabolism by this route was provided by respiration studies on 1-chlorobutane-grown cells which showed high rates of oxygen uptake with 1-chlorobutane, nbutanol and n-butyric acid but negligible oxygen uptake on n-butane and n-pentane (Table 1). Acetate but not succinate was also readily oxidized implying that $n$ butyric acid was probably metabolized by $\beta$-oxidation. When washed resting cells harvested from 1chlorobutane-grown cultures were incubated with 1chlorobutane under anaerobic conditions equimolar nbutanol (confirmed by GC/MS) and chloride ion accumu- lated in the medium suggesting the presence of a hydrolytic dehalogenase.

To ascertain whether any degradation of 1-chlorobutane from the non-halogenated end of the molecule occurred, culture medium $(200 \mathrm{ml})$ from 1-chlorobutane-grown cultures was adjusted to $\mathrm{pH} 6.5$ or $\mathrm{pH} 2.0$ and continuously ether-extracted in an attempt to isolate any trace metabolic intermediates. GC/MS analysis of these extracts revealed the presence of only one unknown compound in significant quantities. The electron impact mass spectrum of the compound exhibited fragments at $\mathrm{m} / \mathrm{z} 86$ (molecular ion, $100 \%), m / z \quad 42\left(M-\mathrm{CO}_{2}, 83 \%\right), \mathrm{m} / \mathrm{z} 56$ $\left(M-\mathrm{CH}_{2} \mathrm{O}, 43 \%\right), m / z 41\left(M-\mathrm{HCO}_{2}, 38 \%\right)$ and $m / z$ $85(M-\mathrm{H}, 25 \%)$. The retention time and mass spectrum of the compound were identical to that of $\gamma$-butyrolactone. The compound was present in both $\mathrm{pH} 6.5$ and $\mathrm{pH} 2.0$ extracts in similar amounts and was detected, albeit in trace quantities, in samples from all stages of growth from $24 \mathrm{~h}$ onwards. A maximum concentration of $5 \mu \mathrm{M}$ was attained as growth peaked at $36 \mathrm{~h}$ but the compound could still be detected in the medium at $3 \mu \mathrm{M}$ when measurements were terminated at $70 \mathrm{~h}$. It seems probable that this compound arises by chemical lactonization of 4 chlorobutyric acid which could be produced by oxygenase attack at the non-chlorinated end of the molecule. Measurement of chloride release from 4-chlorobutyric acid solutions at $\mathrm{pH} 8.0$ indicated a half-life for the compound of about $20 \mathrm{~min}$ rising to $2 \mathrm{~h}$ at $\mathrm{pH} 6.5$ although reduction of the $\mathrm{pH}$ to 3.0 extended the half-life to $22 \mathrm{~h}$. GC/MS examination of diethyl ether extracts of such solutions at both $\mathrm{pH} 6.5$ and 3.0 indicated that $\gamma$ - 
Table 1. Oxidation of various substrates by cell suspensions of $R$. rhodochrous grown on 1-chlorobutane

\begin{tabular}{|lc|}
\hline Substrate & $\begin{array}{c}\mathbf{O}_{2} \text { uptake* } \\
\text { (relative to that } \\
\text { with n-butyric } \\
\text { acid as substrate) }\end{array}$ \\
\hline n-Butyric acid & $100 \dagger$ \\
n-Butanol & 189 \\
4-Chlorobutanol & 113 \\
Butane-1,4-diol & 21 \\
4-Hydroxybutyric acid & 3 \\
Butane & 0 \\
Pentane & 0 \\
1-Chlorobutane & 68 \\
Y-Butyrolactone & 0 \\
Acetic acid & 22 \\
Succinic acid & 0 \\
\hline
\end{tabular}

* Corrected for endogenous $\mathrm{O}_{2}$ uptake.

† Represents an $\mathrm{O}_{2}$ uptake of $668 \mathrm{nM} \mathrm{O}_{2} \min ^{-1}(\mathrm{mg} \text { protein })^{-1}$ after correction for an endogenous rate of $40 \mathrm{nM} \mathrm{O}_{2} \mathrm{~min}^{-1}(\mathrm{mg}$ protein $)^{-1}$.

butyrolactone was the only detectable organic product formed from 4-chlorobutyric acid under these conditions. Under normal cultural conditions this rapid lactonization would ensure that accumulation of significant quantities of 4-chlorobutyric acid in the medium did not occur unless there was substantial production of the compound during bacterial catabolism.

\section{Dehalogenating activity of resting cells of $R$. rhodochrous with various substrates}

1-Butanol-grown cells do not possess dehalogenase activity but growth on 1-chlorobutane induces an enzyme which permits dehalogenation of a number of substrates. The relative activities of 1-chlorobutane-grown resting cells of $R$. rhodocbrous in dehalogenating a range of halogenated substrates is shown in Table 2 , which also indicates which compounds act as growth substrates. Dehalogenation of 1-halosubstituted alkanes with chainlengths between $\mathrm{C}_{3}$ and $\mathrm{C}_{9}$ was observed. The corresponding bromo- and iodo-compounds also appeared to be cleaved at rates similar to those of the chlorocompounds but only a limited release of fluoride from the fluoroalkanes tested was found. The low or insignificant rate of dehalogenation of chloro-, iodo- and bromocompounds with chain-lengths exceeding 10 carbon atoms by resting cells did not appear to affect the ability of these compounds to act as growth substrates implying that enzymic dehalogenation is not the only mechanism available to the organism to initiate degradation of these molecules. Conversely, $C_{5}$ to $C_{8}$ bromo-alkanes, whilst readily dehalogenated by resting cells did not act as growth substrates, suggesting that perhaps these compounds were not capable of inducing expression of the dehalogenase enzyme.
Table 2. Growth of $R$. rhodochrous on various substrates compared with dehalogenating activity of 1 chlorobutane-grown cells for these substrates

Dehalogenation was measured as $\mu \mathrm{mol}$ halide ion released when 0.375 mmols substrate was incubated with $50 \mathrm{ml}$ Tris $/ \mathrm{H}_{2} \mathrm{SO}_{4}$ buffer $(50 \mathrm{mM}, \mathrm{pH} 8 \cdot 0)$ containing $5 \times 10^{6}$ resting cells $\mathrm{ml}^{-1}$ for $24 \mathrm{~h}$ at $25^{\circ} \mathrm{C}$ in a $250 \mathrm{ml}$ bottle. Corrections were made for abiotic halide release and dehalogenation is expressed as a percentage of halide ion released when 1-chlorobutane was substrate. Abiotic dehalogenation of all of the substrates was less than $5 \%$ of the total added over $24 \mathrm{~h}$ with the exception of 5chlorovaleric acid $(30 \%)$. ND, Not determined.

\begin{tabular}{|c|c|c|}
\hline Compound & $\begin{array}{l}\text { Utilization } \\
\text { as growth } \\
\text { substrate }\end{array}$ & Dehalogenation \\
\hline Chloromethane & - & 0 \\
\hline 1-Chloroethane & - & 0 \\
\hline 1-Chloropropane & + & 121 \\
\hline 1-Chlorobutane & + & 100 \\
\hline 1-Chloropentane & + & 112 \\
\hline 1-Chlorohexane & + & 125 \\
\hline 1-Chloroheptane & + & 121 \\
\hline 1-Chlorooctane & + & 43 \\
\hline 1-Chlorononane & - & 35 \\
\hline 1-Chlorodecane & + & 32 \\
\hline 1-Chlorododecane & + & 19 \\
\hline 1-Chlorotetradecane & + & 12 \\
\hline 1-Chlorohexadecane & + & 5 \\
\hline 1-Chlorooctadecane & + & 0 \\
\hline 1-Bromopropane & + & 98 \\
\hline 1-Bromobutane & + & 102 \\
\hline 1-Bromopentane & - & 112 \\
\hline 1-Bromohexane & - & 109 \\
\hline 1-Bromoheptane & - & 110 \\
\hline 1-Bromooctane & - & 135 \\
\hline 1-Bromodecane & + & 48 \\
\hline 1-Bromododecane & + & 20 \\
\hline 1-Bromopentadecane & + & 0 \\
\hline 1-Bromohexadecane & + & 15 \\
\hline 1-Bromooctadecane & + & 8 \\
\hline 1-Iodopropane & + & 92 \\
\hline 1-Iodobutane & + & 30 \\
\hline 1-Iododecane & + & ND \\
\hline 1-Iodododecane & + & 21 \\
\hline 1-Iodohexadecane & + & 0 \\
\hline 1-Iodooctadecane & + & 0 \\
\hline 1-Fluoropentane & - & 1 \\
\hline 1-Fluorohexane & - & 0.6 \\
\hline 1-Fluorotetradecane & + & 0 \\
\hline 2-Chlorobutane & - & 0 \\
\hline 2-Bromobutane & - & 31 \\
\hline 1,4-Dichlorobutane & + & 218 \\
\hline 1,6-Dichlorohexane & + & 121 \\
\hline 3-Chloropropanol & - & 102 \\
\hline 6-Chlorohexanol & + & 79 \\
\hline 1-Chloroacetic acid & - & 0 \\
\hline 3-Chloropropionic acid & - & 12 \\
\hline 5-Chlorovaleric acid & - & 30 \\
\hline R-2-Chloropropionic acid & - & 0 \\
\hline L-2-Chloropropionic acid & - & 0 \\
\hline
\end{tabular}


Dehalogenation of certain diterminally substituted substrates such as 1,4-dichlorobutane also occurred readily but substrates with mid-chain substitutents were not in general attacked. $\omega$-Halo-alcohols were rapidly dehalogenated and the corresponding acids were similarly degraded although chemical lactonization of some of these compounds was also very rapid under the assay conditions used. This made it difficult to determine with accuracy the rate of enzymic dehalogenation of 4chlorobutyric acid in particular and this data is not included. However, both of the homologous acids 3chloropropionic acid and 5-chlorovaleric acid underwent biological dehalogenation at significant rates rendering it not unreasonable to assume that 4-chlorobutyric acid can act as a substrate for enzymic dehalogenation. The overall range of substances dehalogenated by whole cells of $R$. rbodocbrous bears a close resemblance in a number of respects to the substrate specificity of the haloalkane halidohydrolase isolated by Sallis et al. (1990) from $\mathrm{R}$ bodococcus erythropolis, although it will not be possible to assess the precise degree of similarity until the substrate specificity of the purified $R$. rbodocbrous enzyme is determined.

\section{1-Chlorohexadecane degradation by $\boldsymbol{R}$. rhodochrous}

In view of the ready growth of $R$. rbodochrous on higher chlorinated alkanes despite the failure of 1-chlorobutanegrown resting cells of the organism to dehalogenate these substrates, growth of the organism on 1chlorohexadecane was examined in some detail. The time course of growth on the substrate is shown in Fig. 2. Although measurement of optical density provided only an approximate indication of the extent of growth because cells of the organism tended to clump together with this substrate, growth had apparently attained a maximum after between 30 and $70 \mathrm{~h}$ incubation. Disappearance of 1 chlorohexadecane from the culture medium was complete after approximately $70 \mathrm{~h}$ but only about $40 \%$ of the organic chlorine originally present in the substrate had been released as chloride ion by this time, suggesting that chlorinated degradation products were accumulating in the culture medium. Chloride continued to be released into the medium over an extended period of time but even after $20 \mathrm{~d}$ incubation only $80 \%$ mineralization of organic chloride had been achieved. A GC/MS examination of ether extracts of the culture medium at $\mathrm{pH} 6.5$ and 2.0 was conducted in order to identify possible metabolites. Extracts at both pH 6.5 and 2.0 revealed the presence of $\gamma$ butyrolactone. Concentrations of the compound were significantly higher than in 1-chlorobutane-grown cultures and are recorded for the various stages of growth in Fig. 2. $\gamma$-Butyrolactone levels increased during the exponential phase reaching $1 \mathrm{mM}$ as maximum growth was achieved. It would appear that little further metabolism of the compound occurred as concentrations had declined only slightly when measurements were terminated at $120 \mathrm{~h}$.

Analysis of the pH 2 extract after derivatization with diazomethane indicated that the culture medium contained two non-halogenated organic acids which were identified from the mass spectra and retention times of their methyl esters as succinic and 4-hydroxybutyric acids. Both were observed in trace quantities at all stages of growth from $24 \mathrm{~h}$ onwards, each reaching maximum levels as growth peaked at $48 \mathrm{~h}$ when concentrations of succinic and 4-hydroxybutyric acid were respectively $3 \mu \mathrm{M}$ and $5 \mu \mathrm{M}$. A chlorinated organic acid was also detected by GC/MS in the $\mathrm{pH} 2.0$ extract. The electron impact mass spectrum of the methylated acid exhibited fragments at $m / z 74\left[\mathrm{CH}_{2}=\mathrm{C}(\mathrm{OH}) \mathrm{OCH}_{3}, 100 \%\right], m / z$ $105\left(M-\mathrm{OCH}_{3}, 37 \%\right), m / z 59\left(\mathrm{COOCH}_{3}, 18 \%\right), m / z 41$ $(17 \%), m / z .107(12 \%)$ and $m / z .77(11 \%)$. The ratio of ions at $m / z_{1} 105$ and $m / z^{107}$ suggested that the compound contained a chlorine atom. The mass spectrum and retention time of the methyl ester were found to be identical to those of methyl 4-chlorobutyrate. The compound was present at all stages of growth from $24 \mathrm{~h}$ onward attaining a maximum concentration of $6 \mu \mathrm{M}$ at $48 \mathrm{~h}$. Amounts observed were several orders of magnitude too low to explain the incomplete mineralization of organic chlorine noted during growth on 1chlorohexadecane. Experiments involving the incubation of 4-chlorobutyric acid in sterile culture medium indicated that the traces of 4-hydroxybutyric acid found did not arise chemically from 4-chlorobutyric acid or $\gamma$ butyrolactone.

\section{Fatty acid composition of lipids of $\boldsymbol{R}$. rhodochrous}

A report by Murphy \& Perry (1983) that Mycobacterium spp. could incorporate 1-chlorohexadecane into the cellular lipid fraction when growing on the compound as sole carbon and energy source suggested a possible explanation of the low chloride yield during growth of $R$. rbodocbrous on this substrate. Fatty acid compositions of cells harvested after growth on 1-chlorohexadecane, hexadecane and 1-chlorobutane were therefore determined as described in Methods. Although no chlorofatty acids were found in 1-chlorobutane- or hexadecane-grown cells, chlorofatty acids comprised $75 \%$ of the total fatty acid content in 1-chlorohexadecane-grown cells with $\mathrm{C}_{14: 0}, \mathrm{C}_{16: 0}, \mathrm{C}_{16: 1}$ and $\mathrm{C}_{18: 1}$ acids being the major chlorinated compounds (Table 3). Nearly all fatty acids were present in bound form, free fatty acids constituting less than $1 \%$ of the total fatty acids present in 1chlorohexadecane-grown cells. Interestingly the chainlength and degree of unsaturation of the chlorofatty acids were markedly different in a number of respects from those of the unsubstituted fatty acids present in cells grown on hexadecane. Thus although the $C_{16: 0}$ acids were the major components in both hexadecane- and 1chlorohexadecane-grown cells, $\mathrm{C}_{14: 0}$ and $\mathrm{C}_{18: 1}$ acids were present in much enhanced concentrations mainly at the expense of the $C_{16: 1}$ acid in cells growing on the chlorinated substrate. Indeed, surprisingly the fatty acid composition of 1-chlorohexadecane-grown cells with respect to chain-length and degree of unsaturation corresponded more closely to that of 1-chlorobutane-grown cells than hexadecane-grown cells. The reason for this change in the character of the lipid components is not immediately apparent. Nevertheless, quite clearly 1- 
Table 3. Fatty acid composition of cells of $R$. rhodochrous grown on 1-chlorobutane, 1chlorohexadecane or hexadecane

Non-Cl, Non-chlorinated fatty acid; $\mathrm{Cl}$, chlorinated fatty acid.

\begin{tabular}{|c|c|c|c|c|c|c|c|}
\hline \multirow{3}{*}{$\begin{array}{l}\text { Fatty } \\
\text { acid }\end{array}$} & \multicolumn{7}{|c|}{ Percentage of total fatty acids } \\
\hline & \multicolumn{2}{|c|}{$\begin{array}{l}\text { 1-Chlorobutane- } \\
\text { grown cells }\end{array}$} & \multicolumn{3}{|c|}{$\begin{array}{l}\text { 1-Chlorohexadecane- } \\
\text { grown cells }\end{array}$} & \multicolumn{2}{|c|}{$\begin{array}{c}\text { Hexadecane-grown } \\
\text { cells }\end{array}$} \\
\hline & Non-CI & $\mathrm{Cl}$ & Non-Cl & $\mathbf{C l}$ & Total & Non-C1 & $\mathrm{Cl}$ \\
\hline$C_{6: 0}$ & - & - & - & $0 \cdot 8$ & $0 \cdot 8$ & - & - \\
\hline $\mathrm{C}_{8: 0}$ & - & - & - & $4 \cdot 6$ & $4 \cdot 6$ & $1 \cdot 2$ & - \\
\hline$C_{10: 0}$ & - & - & - & $3 \cdot 8$ & $3 \cdot 8$ & $3 \cdot 0$ & - \\
\hline$C_{12: 0}$ & $4 \cdot 1$ & - & - & - & - & $1 \cdot 0$ & - \\
\hline$C_{14: 0}$ & $14 \cdot 9$ & - & $1 \cdot 1$ & $16 \cdot 4$ & $17 \cdot 5$ & $7 \cdot 0$ & - \\
\hline$C_{14: 1}$ & - & - & - & - & - & $0 \cdot 7$ & - \\
\hline$C_{15: 0}$ & $1 \cdot 9$ & - & $2 \cdot 1$ & $1 \cdot 6$ & $3 \cdot 7$ & $0 \cdot 7$ & - \\
\hline$C_{16: 0}$ & $34 \cdot 6$ & - & $15 \cdot 1$ & $27 \cdot 4$ & $42 \cdot 5$ & $45 \cdot 3$ & - \\
\hline$C_{16: 1}$ & $8 \cdot 5$ & - & $3 \cdot 0$ & $10 \cdot 2$ & $13 \cdot 2$ & $38 \cdot 1$ & - \\
\hline$C_{17: 0}^{10.1}$ & - & - & - & - & - & $0 \cdot 9$ & - \\
\hline$C_{18: 0}$ & $2 \cdot 6$ & - & - & - & - & $0 \cdot 1$ & - \\
\hline$C_{18: 1}$ & $15 \cdot 6$ & - & $3 \cdot 7$ & $9 \cdot 9$ & $13 \cdot 6$ & $1 \cdot 5$ & - \\
\hline$C_{19: 0}$ & $9 \cdot 3$ & - & 0.3 & - & $0 \cdot 3$ & $0 \cdot 5$ & - \\
\hline $\mathrm{C}_{20: 0}$ & 8.5 & - & - & - & - & - & - \\
\hline Total & 100 & 0 & $25 \cdot 3$ & $74 \cdot 7$ & 100 & 100 & 0 \\
\hline
\end{tabular}

chlorohexadecane is degraded via the methyl end of the molecule and the chlorinated $\mathrm{C}_{16: 0}$ acid formed is not only assimilated into the cellular lipids per se and $\beta$-oxidized to the $C_{14: 0}$ acid but is readily desaturated to the $C_{16: 1}$ acid and chain-lengthened to the $\mathrm{C}_{18: 1}$ compound. Conversion of the $\mathrm{C}_{16: 0}$ chloroacid to the $\mathrm{C}_{16: 1}$ and $\mathrm{C}_{18: 1}$ chloroacids occurred to a much greater extent in $\mathrm{R}$. rbodochrous than was reported for Mycobacterium spp. by Murphy \& Perry (1983). In the latter investigation the main chloroacids after growth on 1-chlorohexadecane were $C_{16: 0}$ and its $\beta$ oxidation product $\mathrm{C}_{14: 0}$ which together comprised $88 \%$ of the total chlorofatty acids content. In R. rhodochrous by comparison $\mathrm{C}_{\mathbf{1 6 : 0}}$ and $\mathrm{C}_{14: 0}$ chloroacids amounted to only $59 \%$ of the total chlorofatty acids present.

\section{DISCUSSION}

The postulated routes by which 1-chlorobutane and 1chlorohexadecane are degraded by $R$. rhodocbrous are summarized in Fig. 3. Catabolism of 1-chlorobutane is initiated principally by attack at the $\mathrm{C}-1$ atom by a hydrolytic dehalogenase resulting in the formation of $n$ butanol which is oxidized to n-butyric acid and metabolized by $\beta$-oxidation via acetate. The dehalogenase has recently been purified and characterized by Stafford (1993). However, the presence of trace quantities of $\gamma$ butyrolactone in the culture medium indicates that a small proportion of 1-chlorobutane is metabolized via attack at the non-chlorinated end of the molecule to form 4chlorobutyric acid which cyclizes with elimination of chloride to $\gamma$-butyrolactone which appears to be resistant to further degradation. Although $\gamma$-butyrolactone and 4hydroxybutyric acid can both act as substrates for growth of $R$. rhodochrous, induction of enzymes for the catabolism of each occurs only after 9 to $10 \mathrm{~d}$ incubation in the presence of the compound (at $1.5 \mathrm{mM}$ ).

The wide haloalkane substrate range of $\mathrm{R}$. rhodochrous is similar to that reported for R. erythropolis $\mathrm{Y} 2$ by Sallis $e$ t al. (1990) who also noted that this bacterium could grow on terminally halogenated $\mathrm{C}_{14}, \mathrm{C}_{16}$ and $\mathrm{C}_{18}$ alkanes without showing any short-chain haloalkane dehalogenase activity. They suggested that this might be due to the presence in the organism of another dehalogenase specific for long-chain haloalkanes. This explanation was supported by evidence from Scholtz et al. (1988) that Artbrobacter HA1 possessed several different haloalkane halohydrolases. However, although HA1 could grow on 1-bromohexadecane, no dehalogenase activity against this compound was detected in cell-free extracts. As is the case for R. erytbropolis Y2 (Sallis et al., 1990), the dehalogenase of R. rhodocbrous is inducible. However, we have found that $\mathrm{C}_{5}$ to $\mathrm{C}_{8}$ bromoalkanes cannot act as growth substrates even though they are attacked by the dehalogenase induced by growth on 1-chlorobutane. Unlike their chloro-analogues, these compounds do not appear to act as inducers. This indicates an intriguing specificity for the repressor system functioning in this bacterium and may provide a means to further study the regulation of dehalogenase expression through the selection of repressor mutants.

In contrast, 1-chlorohexadecane appears to be metabol- 

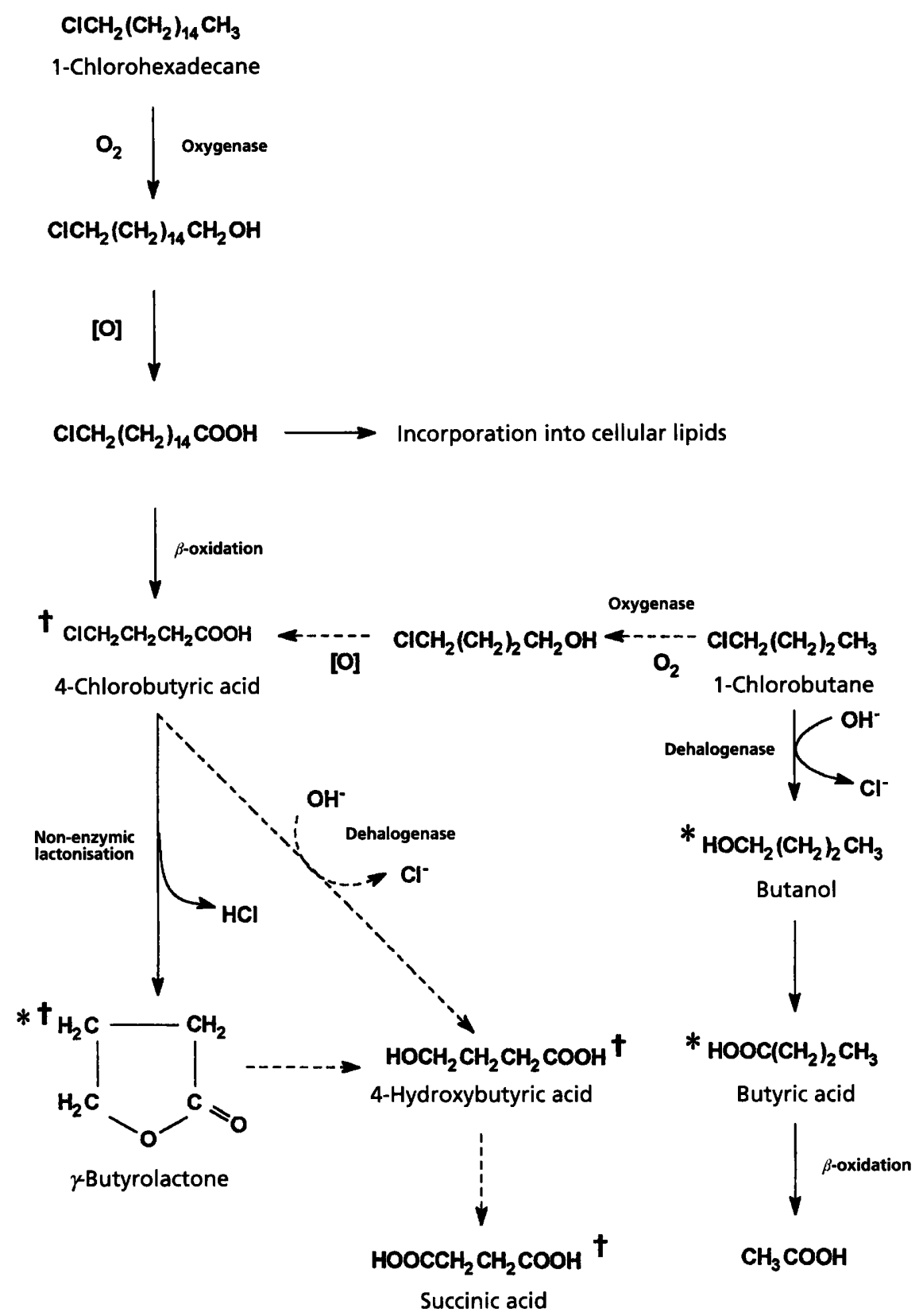

Fig. 3. Possible routes of degradation of 1-chlorobutane and 1-chlorohexadecane in $R$. rhodochrous NCIMB 13064 . * Metabolites detected in medium during growth on 1-chlorobutane; t metabolites detected in medium during growth on 1-chlorohexadecane.

ized by $R$. rbodocbrous predominantly via initial attack on the non-halogenated end of the molecule with degradation proceeding by $\beta$-oxidation until 4-chlorobutyric acid is formed. Two potential fates are then conceivable for the compound: spontaneous cyclization to $\gamma$-butyrolactone or dehalogenase attack with the formation of 4hydroxybutyric acid which is subsequently metabolized via succinic acid and the TCA cycle. The accumulation of $1 \mathrm{mM} \gamma$-butyrolactone in the culture medium during the growth phase when total chloride release into the medium is about $1.6 \mathrm{mM}$ suggests that most of the 4-chlorobutyric acid formed is subject to chemical lactonization. The resistance of $\gamma$-butyrolactone to further degradation can be ascribed to relatively slow induction of enzymes for its catabolism. However, the traces of 4-hydroxybutyric acid and succinic acid found in the culture medium suggest that further metabolism of $\gamma$-butyrolactone can occur. Both compounds have been implicated in the degradation of tetrahydrofuran via $\gamma$-butyrolactone by a Rhodococcus $\mathrm{sp}$. studied by Bernhardt \& Diekmann (1991). If the dehalogenase induced during growth on 1-chlorobutane is also induced during growth on 1-chlorohexadecane a proportion of the 4-chlorobutyric acid formed could be subject to enzymic dehalogenation as the enzyme is 
capable of utilizing $\omega$-chlorofatty acids as substrates (Table 2). Thus although it was not possible to determine the rate of enzymic dehalogenation of 4-chlorobutyric acid itself, both of the homologues 3-chloroproprionic acid and 5-chlorovaleric acid were subject to enzyme attack. However, evidence obtained by Stafford (1993) using enzyme-specific antibody probes suggests that the dehalogenase is not induced to any significant extent during growth on 1-chlorohexadecane. Thus it seems unlikely that appreciable enzymic dehalogenation of 4chlorobutvric acid occurs.

The incorporation of the product of oxygenase attack on 1-chlorohexadecane, 16-chlorohexadecanoic acid, directly into cellular lipids represents a third route of substrate assimilation and accounts at least in part for the incomplete mineralization of the chlorinated substrate. It is possible that chlorinated alkanes are also incorporated into the mycolic acids which can constitute up to $60 \%$ of the dry weight of the cell envelope of nocardioform bacteria of this type (Fox et al., 1990). The slow release of chloride over an extended period after maximum growth was achieved on 1-chlorohexadecane may reflect a slow metabolic turnover of this large cellular fraction during the stationary phase involving various catabolic enzymes including the dehalogenase.

Chain-length would seem to be the primary factor determining whether degradation of 1-haloalkanes is initiated mainly by attack on the halogenated or the nonhalogenated end of the alkane molecule with dehalogenase attack predominating with chain-lengths of $\mathrm{C}_{10}$ and less whilst oxygenase attack dominates at chain-lengths of $\mathrm{C}_{12}$ and above. The co-existence of a dehalogenase enzyme and a propensity to assimilate long-chain haloalkanes directly into lipids in a single organism raises important questions as regards biological treatment of haloalkanecontaining effluent. Consideration may need to be given to the harvesting and safe disposal of biomass after such treatment.

\section{REFERENCES}

Bagley, D. M. \& Gossett, J. M. (1990). Tetrachloroethane transformation to trichloroethene and cis-1,2-dichloroethene by sulphate-reducing enrichment cultures. Appl Environ Microbiol 56, 25112516.

Bernhardt, D. \& Diekmann, H. (1991). Degradation of dioxane, tetrahidrofuran and other cyclic ethers by an environmental Rhodociocus strain. Appl Microbiol Biotechnol 36, 120-123.

Bouwer, E. J. \& McCarty, P. L. (1983). Transformations of halogenated organic compounds under denitrification conditions. Appl Environ . Vicrobiol 45, 1295-1299.

Dunlap, K. R. \& Perry, J. J. (1967). Effect of substrate on the fatty acid composition of hydrocarbon utilizing microorganisms. $J$ Bacteriol 94, 1919-1923.

Elfaki, A. E., Dirar, H. A., Collins, M. A. \& Harper, D. B. (1991). Biochemical and microbiological investigations of sigda-a Sudanese fermented food derived from sesame oilseed cake. $J \mathrm{Sci}$ Food leric 57, 351-365.

Fox, A., Gilbart, J. \& Morgan, S. L. (1990). Analytical microbiology : a perspective. In .Analytical Microbiology Metbods. Cbromatograpby and
Mass Spectrometry, pp. 1-17. Edited by A. Fox, S. L. Morgen, L. Larsson \& G. Odham. New York: Plenum Press.

Janssen, D. B., Scheper, A., Dijkhuizen, L. \& Witholt, B. (1985). Degradation of halogenated aliphatic compounds by Xantbobacter autotropbicus GJ10. Appl Environ Microbicl 49, 673-677.

Janssen, D. B., Jager, D. \& Witholt, B. (1987). Degradation of nhaloalkanes and $\alpha, \omega$-dichloroalkanes by wild-type and mutants of Acinetobacter sp. strain GJ70. Appl Eniron Microbiol 53, 561 -566.

Janssen, D. B., Gerritse, J., Brackman, J., Kalk, C., Jager, D. \& Witholt, B. (1988a). Purification and characterization of a bacterial dehalogenase with activity toward halogenated alkanes, alcohols and ethers. Eur J Biochem 171, 67-72.

Janssen, D. B., Grobben, G., Hoekstra, R., Oldenhuis, R. \& Witholt, B. (1988b). Degradation of trans-1,2-dichloroethene by mixed and pure cultures of methanotrophic bacteria. Appl Microbiol Biotechnol 29, 392-399.

Keuning, S., Janssen, D. B. \& Witholt, B. (1985). Purification and characterization of a hydrolytic haloalkane dehalogenase from Xantbobacter autotropbicus $G J 10$. J Bacteriol 163, 635-639.

Kohler-Staub, D. \& Leisinger, T. (1985). Dichloromethane dehalogenase from Hyphomicrobium sp. IM2. J Bacteriol 162, 676-681.

Marks, T. S., Allpress, J. D. \& Maule, A. (1989). Dehalogenation of lindane by a variety of porphyrins and corrins. Appl Environ Microbiol 55, 1258-1261.

Murphy, G. L. \& Perry, J. J. (1983). Incorporation of chlorinated alkanes into fatty acids of hydrocarbon-utilizing mycobacteria. $J$ Bacteriol 156, 1158--1164.

Murphy, G. L. \& Perry, J. J. (1984). Assimilation of chlorinated alkanes by hydrocarbon-utilizing fungi. J Bacterio/ 160, 1171-1174.

Oldenhuis, R., Vink, R. L. J. M., Janssen, D. B. \& Witholt, B. (1989). Degradation of chlorinated aliphatic hydrocarbons by Metbylosinus trichosporium OB3b expressing soluble methane monooxygenase. Appl Environ Microbiol 55, 2819-2826.

Rasche, M. E., Hicks, R. E., Hyman, M. R. \& Arp, D. J. (1990). Oxidation of monohalogenated ethanes and $\mathbf{n}$-chlorinated alkanes by whole cells of Nitrosomonas europaea. J Bacteriol 172, 5368- 5373.

Sallis, P. J., Armfield, S. J., Bull, A. T. \& Hardman, D. J. (1990). Isolation and characterization of a haloalkane halidohydrolase from Rbodococcus erytbropolis Y2. J Gen Microbiol 136, 115-120.

Scholtz, R., Leisinger, T., Suter, F. \& Cook, A. M. (1987a). Characterization of 1 -chlorohexane halidohydrolase, a dehalogenase of wide substrate range from an Artbrobacter sp. J Bacteriol 169, 5016-5021.

Scholtz, R., Schmuckle, A., Cook, A. M. \& Leisinger, T. (1987b). Degradation of eighteen 1-monohaloalkanes by Artbrobacter sp. HA1. J Gen Microbiol 133, 267-274.

Scholtz, R., Messi, F., Leisinger, T. \& Cook, A. M. (1988). Three dehalogenases and physiological restraints in the biodegradation of haloalkanes by .Artbrobacter sp. strain HA1. Appl Environ Microbiol 54, 3034-3038.

Stafford, T. M. (1993). The microbial degradation of cbloroalkanes. PhD thesis. The Queens University of Belfast, Belfast, LK.

Stirling, D. J. \& Dalton, H. (1979). The fortuitous oxidation and cometabolism of various carbon compounds by whole-cell suspensions of Metbylococcus capsulatus (Bath). FEMS Microbiol Lett 5, 315-318.

Stucki, G., Galli, R., Ebersold, H. R. \& Leisinger, T. (1981). Dehalogenation of dichloromethane by cell extracts of Hyphomicrobium DM2. Arch Microbiol 130, 366371.

Vannelli, T., Logan, M., Arciero, D. M. \& Hooper, A. B. (1990). Degradation of halogenated aliphatic compounds by the ammonia- 
oxidizing bacterium Nitrosomonas europaea. Appl Environ Microbiol 56, 1169-1171.

Van den Wijngaard, A. J., Van der Kamp, K. W. H. J. J., Van der Ploeg, J., Pries, F., Kazemier, B. \& Janssen, D. B. (1992). Degradation of 1,2-dichloroethane by Ancylobacter aquaticus and other facultative methylotrophs. Appl Environ Microbiol 58, 976-983.

Vogel, T. M. \& McCarty, P. L. (1985). Biotransformation of tetrachloroethylene to trichloroethylene, dichloroethylene, vinyl chlor- ide and carbon dioxide under methanogenic conditions. Appl Environ Microbiol 49, 1080-1083.

Yokota, T., Omori, T. \& Kodama, T. (1987). Purification and properties of haloalkane dehalogenase from Corynebacterium sp. strain m15-3. J Bacteriol 169, 4049-4054.

Received 9 November 1993; revised 5 January 1994; accepted 11 January 1994. 